Article

\title{
Renewable Energy Development as a Driver of Economic Growth: Evidence from Multivariate Panel Data Analysis
}

\author{
Nadia Singh *, Richard Nyuur and Ben Richmond \\ Newcastle Business School, Northumbria University, Newcastle NE1 8ST, UK; \\ richard.nyuur@northumbria.ac.uk (R.N.); beric489@hotmail.co.uk (B.R.) \\ * Correspondence: nadia.singh@northumbria.ac.uk
}

Received: 5 March 2019; Accepted: 13 April 2019; Published: 24 April 2019

check for updates

\begin{abstract}
Renewable energy is being increasingly touted as the "fuel of the future," which will help to reconcile the prerogatives of high economic growth and an economically friendly development trajectory. This paper seeks to examine relationships between renewable energy production and economic growth and the differential impact on both developed and developing economies. We employed the Fully Modified Ordinary Least Square (FMOLS) regression model to a sample of 20 developed and developing countries for the period 1995-2016. Our key empirical findings reveal that renewable energy production is associated with a positive and statistically significant impact on economic growth in both developed and developing countries for the period 1995-2016. Our results also show that the impact of renewable energy production on economic growth is higher in developing economies, as compared to developed economies. In developed countries, an increase in renewable energy production leads to a 0.07 per cent rise in output, compared to only 0.05 per cent rise in output for developing countries. These findings have important implications for policymakers and reveal that renewable energy production can offer an environmentally sustainable means of economic growth in the future.
\end{abstract}

Keywords: renewable energy; economic growth; sustainability; panel data regression; developing economies; developed economies

\section{Introduction}

Energy has been a pivot of economic development and industrialization since time immemorial [1]. It is believed that there is a linear and positive relationship between the growth of national economies and energy consumption [2]. In recent years, there has been growing impetus on renewable energy production in the global energy sector and it is being increasingly touted as the "fuel of the future." However, the inter-linkages between renewable energy sector and economic growth have not been clearly understood in literature so far. Also, the differential impacts of renewable energy production in developing and developed economies have not been systematically analysed. Most studies have either focused on developed countries or developing countries separately, while analysing the inter-linkages between economic growth and renewable energy deployment. In addition to this, the existing literature has solely focused on GDP per capita as an indicator of economic growth. Other indicators such as labour force participation rate and gross capital formation have been largely relegated to the background. This paper aims to contribute to these critical, yet under-researched areas surrounding renewable energy production. In this paper, we have analysed the differential impacts of renewable energy production on both developed and developing countries. Instead of focusing on gross domestic product (GDP) per capita as the sole criterion of economic growth, we have expanded the discussion to include 
other indicators such as total labour force and gross fixed capital formation as well. This paper thus has important theoretical as well as policy implications in the arena of renewable energy production. At the theoretical level, it will help to expand the understanding of the channels through which renewable energy deployment affects economic growth. At a practical level, it can help policymakers to devise better policy mechanisms to expand on the contribution of renewable energy to key economic variables such as employment and capital formation.

The global energy system is primarily based on fossil fuels, which contribute to over eighty per cent of the total energy supply in the world economy [3]. However, in recent years, some major challenges related to the use of fossil fuel energy have emerged. These challenges include the growing mismatch between energy demand and supply in the global economy [4], increasing threat of exhaustion of oil reserves [5] as well as high level of greenhouse gas emissions in the atmosphere [6]. Carbon generated from the production of fossil fuels is now recognised as the "dominant cause of the ecological crisis facing humanity" [6].

In view of these manifold crises in the energy sector, there has been increasing impetus on the development of "clean" renewable sources of energy in recent years. As environmental degradation continues at an unabated rate, many developed and developing countries are moving forward towards a "green" growth agenda, so that economic growth and environmental conservatism can work in tandem with each other [7]. A major focus of this "green" growth agenda is the mainstreaming of renewable energy technologies and creating a viable green energy market [8]. Renewable energy technologies are being promoted as the "next green revolution" which will help to reconcile the prerogatives of high economic growth and an environmentally friendly development trajectory $[9,10]$.

Renewable energy deployment is also one of the 17 sustainable development goals, initiated by the United Nations in 2015 [11]. The use of renewables is growing equally fast in developed and developing countries. The year 2015 marked the first time that developing countries invested more in renewables than developed countries. Much of the increased investment in renewable energy is driven by China, which accounted for $32 \%$ of the financing behind renewables in 2016 according to the Renewable Energy Network [12].

It is contended that renewable energy can play an important role in "decarbonizing" energy, which is a key aspect of climate change mitigation. Renewables currently contribute to $19.3 \%$ to global energy consumption and contribute significantly to the levelling off of carbon emissions [12]. A study by Fang [13] revealed that renewable energy consumption could help to reduce carbon emissions by roughly $8.2 \%$ by the year 2050 . The deployment of renewable energy technologies also has distinct economic advantages. Renewables have the potential to reduce dependency on imported fuel and solve the issues of energy access for over 1.4 billion people across the globe who remain "energy poor" [14]. Renewable energy deployment can also help to create jobs [15] and foster the development of small-scale industries in the rural areas of developing countries [16]. According to Fang [13] an increase in renewable energy consumption by $1 \%$ point increases GDP per capita by $0.12 \%$ points. However, some studies have also gathered contradictory evidence on the inter-linkages between economic growth and renewable energy consumption. For instance, empirical studies by Apergis and Payne [17-19] and Salim et al. [20] show that renewable energy production does not have net positive effect on employment generation. Other studies by Hall et al. [21] and Weibbach et al. [22] revealed that with the current level of technology, the Energy Returns on Investment (EROI) for renewable energy are three times lower than fossil fuel energy. Both these studies concluded that with the current level of technology it is highly unlikely that renewable energy will be a viable energy alternative in the near future.

Thus, the empirical evidence on the inter-linkages between renewable energy deployment and economic growth remain inconclusive and scattered. This paper aims to contribute to this crucial area. In particular this paper seeks to differentiate between the relative importance of renewable energy and fossil fuel energy on economic growth by analysing separate panels for developed and developing countries. This comparison is relevant in light of the fact that developed and developing economies 
are projected to have separate energy needs in the future. According to the estimates by International Energy Outlook [23] the energy consumption in developing and emerging economies is projected to increase by 84 per cent between 2007-2035. On the other hand, in case of developed economies, energy consumption is projected to increase by 14 per cent between 2007-2035.

We examine the impact of renewable energy production on economic growth, gross capital formation and labour force participation, using panel data analysis of ten developed and ten developing economies for the period 1990-2016. The main research question that this paper seeks to answer is whether renewable energy is a driver of economic growth. This research question is further broken down into 4 sub-questions

(1) Does renewable energy production have a significant impact on real GDP?

(2) Does renewable energy production have a significant impact on gross fixed capital formation?

(3) Does renewable energy production have a significant impact on the size of the labour force?

(4) Is there a differential impact on renewable energy production in developed and developing countries?

The remainder of the paper is organised as follows: Section 2 reviews the existing empirical literature on the inter-linkages between renewable energy deployment and economic growth. Section 3 describes the methodology of the study. Section 4 discusses the empirical results. Section 5 presents the final conclusion.

\section{Literature Review: Renewable Energy Development and Economic Growth}

A key question in the sustainable development discourse is to what extent the mitigation of carbon emissions through renewable energy use can contribute to economic growth [24]. In traditional economic literature, these inter-linkages between economic growth and environmental degradation are understood in terms of the Environmental Kuznets Curve (EKC). The EKC postulates, "Environmental degradation increases with growing income up to a threshold level, beyond which, environmental quality improves with higher income per capita" [25]. The EKC is explained by a combination of scale effects (some pollution control technologies become viable with increasing economies of scale), combination effects (the movement from basic inefficient industries to "clean" service based industries) and the technique effects (use of less polluting inputs per unit of output) [26].

The EKC has been extensively analysed in the literature. Seldon and Song [27] first confirmed the existence of an EKC. They used a sample of 42 developing economies for the period 1971-9991 and showed that per capita emissions of carbon monoxide, sulphur dioxide, nitrous oxide and particulate matter exhibit negative relationships with per capita GDP. In recent years, the existence of the EKC was also confirmed by other studies such as Lamla [28], Apergis and Ozturk [29] and Jebli et al. [30]. However, the evidence remains mixed. For instance, Jebli and Youssef [31] showed that the EKC hypothesis did not hold true in the case of Tunisia, using data from the period 1980-2019. The same conclusion was reached by Ozturk and Acaravci [32] on the basis of Turkish data for the period 1968-2015. In another study, Ozokcu and Ozdemir [33] showed that the EKC hypothesis did not hold true for a sample of 26 high-income OECD countries as well as 52 emerging economies for the period 1960-2010.

The EKC hypothesis was explored in the context of renewable energy deployments by a number of studies. Al-Mulai, Ozturk and Solarin [34] analysed data for seven regions: Central and Eastern Europe, Western Europe, East Asia and the Pacific, South Asia and the Americas for the period 1980-2010 and concluded that the existence of the EKC is significantly determined by the importance of renewable energy consumption in the given geographical area. In another study, Bilgli et al. [35] used a panel data set of 17 Organisation for Economic Co-operation and Development (OECD) countries for the period 1977-2010 to show that EKC hypothesis holds true. The analysis also revealed that renewable energy consumption yields negative impact on $\mathrm{CO}_{2}$ emissions and a positive impact on GDP per capita and 
GDP per capita squared. A similar conclusion was reached by Lopez-Menendez et al. [36] for a panel of 27 EU countries between the period 1996-2010.

The causal relationship between economic growth and renewable energy development is also explained in the literature in the form of four testable hypotheses: growth hypothesis, conservation hypothesis, feedback hypothesis and neutrality hypothesis [37,38]. These are summarised in Figure 1 below:

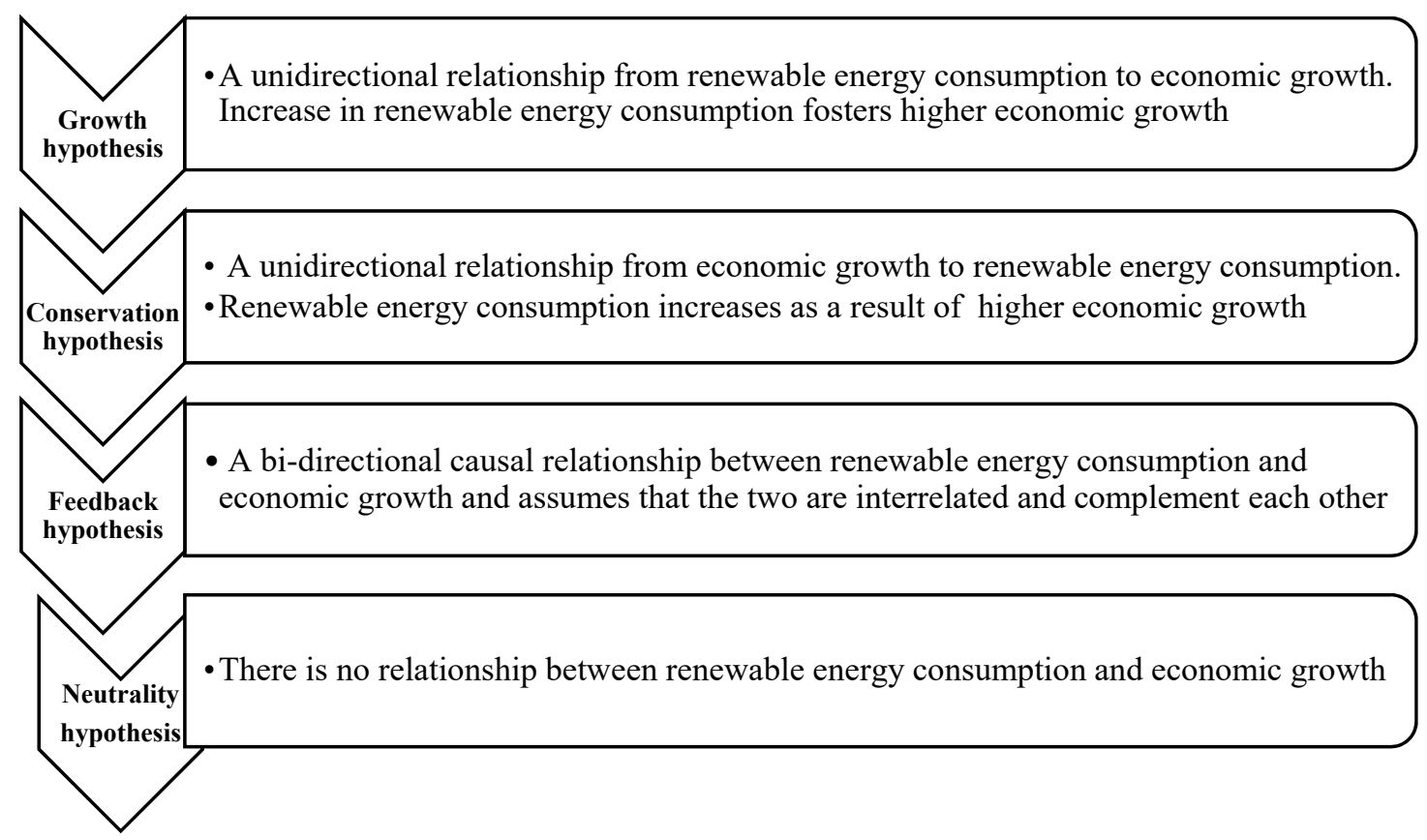

Figure 1. Testable hypothesis on the relationship between renewable energy consumption and economic growth. Source: Authors' compilation based on review of literature

A number of empirical studies have tried to examine this causal relationship between renewable energy consumption and economic growth in recent years by using the above testable hypothesis $[17,19,20,38-42]$. The results of these studies however, differ widely based on the selected samples, employed variables and the quantitative methods that were used in the research. The key results from these studies are summarized below.

\subsection{Growth Hypothesis}

On the basis of panel estimation techniques for the 38 top renewable energy-producing countries for the period 1990-2012, Bhattacharya et al. [39] found that renewable energy consumption had a "significant positive impact" on long-run economic growth in $57 \%$ of the countries selected. This supports the growth hypothesis and implies that renewable energy consumption is a driver for economic growth. This is congruent with findings from Ito [40]. He employed conventional OLS estimates, along with Dynamic OLS estimates on a sample of 42 developing countries for the period 1980-2009 and found that in the long-run, renewable energy consumption had a positive effect on economic growth. In another study, Inglesi-Lotz [41] employed Pedroni co-integration technique on a sample of 34 OECD countries for the period 1990-2010. In addition, Omri et al. [38] used dynamic simultaneous-equation panel data model for 17 developed and developing countries for the period 1990-2011. This study found that the growth hypothesis holds true in Hungary, India, Japan, Netherlands and Sweden. In another study Pao and Fu [42] employed Vector Error Correction model for the Brazilian economy between the time period, 1980-2010 and found evidence of unidirectional causality between renewable energy consumption and economic growth. The growth hypothesis has also been supported by Bilgili and Ozturk [35] for a panel of G7 countries for the period 1980-2009 and 
by Ozturk and Bilgili [43] for a panel of 51 Sub-Saharan African countries for the period 1980-2009. Based on these, we hypothesise that:

Hypothesis 1. Renewable energy production is a driver of economic growth.

\subsection{Feedback and Conservation Hypothesis}

A number of studies have also emerged in support of the feedback hypothesis in recent years. Apergis and Payne [17] showed evidence of bi-directional causality between renewable energy consumption and economic growth for 20 OECD countries for the period 1985-2005. Similar findings were reported for a sample of six Central American countries for the period 1980-2016 [19], a panel of 80 developing countries for the period 1990-2007 [44] and for Middle East and North Africa (MENA) Net Oil Importing Countries for the period 1980-2012 [45]. All these studies employed the Panel Vector Error Correction (PVEC) models.

In addition to the growth and feedback hypothesis, support for the conservation hypothesis is also substantial. Sadorsky [46] adopted panel co-integration estimations for a panel of eighteen emerging economies for the period 1994-2003. This study concluded that a 1\% increase in real income per capita would lead to a $3.5 \%$ increase in renewable energy consumption, implying that renewable energy consumption will escalate heavily as emerging economies take off. In another study, Menyah and Wolde-Rufael [47] employed the Granger causality test on US data for the period 1960-2007 and found evidence of unidirectional causality from GDP growth to renewable energy consumption. The conservation hypothesis was also confirmed in the case of Turkey by two studies-Lise and Montfort [48] and Ocal and Aslan [49]. Lise and Montfort [48] provided evidence for the conservation hypothesis in Turkey for the period 1970-2003 based on the Auto-Regressive Distributive Lag (ARDL) model. On the other hand, Ocal and Aslan [49] used the Toda-Yamamoto causality tests and confirmed the conservation hypothesis in Turkey for the period 1990-2010.

\subsection{Neutrality Hypothesis}

Despite the considerable wealth of research that supports a uni/bidirectional relationship between renewable energy deployment and economic growth, numerous counteracting studies suggest that there exists no such relationship. For instance, Menegaki [50] conducted Granger causality tests on EU data for the period 1997-2007 and found no evidence of any relationship between renewable energy consumption and economic growth in Europe. He has argued that the non-existent existent causality (defined as the lack of any causal relationship) between GDP and Renewable Energy consumption may be due to the early stages of development and market penetration of renewable energy in Europe during this period. Nonetheless, similar findings were reported by Yildirim, Sarac and Aslan [51] in their analysis of the US economy for the period 1949-2006 on the basis of Toda-Yamamoto causality tests. In another study, Vaona [52] confirmed the existence of the neutrality hypothesis for Italy for the period 1861-2001 on the basis of Granger's causality tests.

Thus, from the review of the literature in this section, one can conclude that there is no clear evidence of the direction and the type of relationship between renewable energy consumption and economic growth. In recent years, studies have also shown evidence of mixed results. For instance, Huang et al. [53] used panel data modelling for a sample of 82 countries for the period 1972-2002. The study found that the neutrality hypothesis holds true for low-income category countries and conservation hypothesis for middle-income category countries. In another study, Al-Mulai et al. [34] analysed 108 countries for the period 1980-2009 and established bi-directional causality within 79 per cent of the countries, neutrality hypothesis within 19 per cent of the countries and unidirectional causality from growth to renewable energy within 2 per cent of the countries. In a recent study, Ntanos et al. [54] employed autoregressive distributive lag model and analysed the relationship between renewable energy consumption and economic growth for EU countries during the period 
2007-2016. They found that the growth hypothesis holds true for countries with a higher level of GDP per capita, while the neutrality hypothesis holds true for countries with lower levels of GDP per capita. A similar conclusion was also reached by Alper and Oguz [55], Khalmova et al. [56] and Rodríguez-Monroy et al. [57].

If we consider the impact of renewable energy production on employment creation, we find that, in theory, renewable energy production is believed to be much more labour intensive than conventional sources of energy [58]. Some studies have shown that renewable energy production leads to a net increase in employment [59-61]. However, other studies, such as Frondel et al. [62], have shown that the net employment generation through renewable energy production is zero or even negative in the long-run. Thus, the evidence on the effects of renewable energy generation on employment generation remains largely inconclusive. There have also been very few studies that have examined the impact of renewable energy generation on gross fixed capital formation. However, the few studies that have examined this relationship, such as Apergis and Payne [17-19], have all concluded that the impact of renewable energy generation on gross fixed capital formation is positive. On the other hand, Salim et al. [20] found no evidence of any relationship between renewable energy production and gross fixed capital formation in developing countries.

Based on these discussions in this paper we further hypothesise that:

Hypothesis 2. Renewable energy production increases gross fixed capital formation.

Hypothesis 3. Renewable energy production increases labour force participation.

Hypothesis 4. Renewable energy production has differential economic impacts in developed and developing economies.

\section{Methodology}

\subsection{Sample Selection and Hypothesis Testing}

This paper follows a panel of ten developing and ten developed economies for the period 1995-2016, acquired from the World Development Indicators (WDI) of the World Bank [63] and the Energy Information Agency [64]. The multivariate framework includes real gross domestic product (Real GDP) as a proxy for economic growth, gross fixed capital formation (GFCF), total labour force (LF), renewable energy production (REP) and fossil fuel (FF) use. These variables are explained in Table 1 below:

Table 1. Exhibition of the variables.

\begin{tabular}{|c|c|c|c|}
\hline Variable & Description & Period & Source \\
\hline Real GDP & $\begin{array}{l}\text { Real Gross Domestic Product is the market value of all final goods and } \\
\text { services produced in the economy during a given period of time. It is } \\
\text { measured in billions of constant US\$ (2000). }\end{array}$ & 1995-2016 & $\begin{array}{l}\text { World Development } \\
\text { Indicators }\end{array}$ \\
\hline GFCF & $\begin{array}{l}\text { Gross fixed capital formation includes land improvements, plant, machinery } \\
\text { and equipment purchases; and the construction of roads, railways and the } \\
\text { like, including schools, offices, hospitals, private residential dwellings and } \\
\text { commercial and industrial buildings. It is measured in billions of constant } \\
\text { US\$ (2000). }\end{array}$ & 1995-2016 & $\begin{array}{l}\text { World Development } \\
\text { Indicators }\end{array}$ \\
\hline LF & $\begin{array}{l}\text { Labour force LF, refers to the supply of labour for the production of goods } \\
\text { and services. It is measured in millions }\end{array}$ & 1995-2016 & $\begin{array}{l}\text { World Development } \\
\text { Indicators }\end{array}$ \\
\hline REP & $\begin{array}{l}\text { Renewable Energy Production is defined as electricity production from } \\
\text { renewable sources, includes geothermal, solar, tides, wind, biomass and } \\
\text { biofuels. It is measured in million of kilowatt-hours (kwh). }\end{array}$ & 1995-2016 & $\begin{array}{c}\text { US Energy } \\
\text { Information Agency }\end{array}$ \\
\hline FF & $\begin{array}{l}\text { Fossil Fuels FF are defined as electricity generation that consists of electricity } \\
\text { generated from coal, petroleum and natural gas. It is measured in million of } \\
\text { kilowatt-hours }(\mathrm{kwh}) \text {. }\end{array}$ & 1995-2016 & $\begin{array}{c}\text { US Energy } \\
\text { Information Agency }\end{array}$ \\
\hline
\end{tabular}

Source: Authors' compilation. 
The main question examined in this paper is to establish whether renewable energy production can be a driver of economic growth in a region. In order to analyse the economic benefits of renewable energy production, we have analysed its relationship with real GDP, GFCF and total LF. These variables are relevant in view of the fact that in the traditional production function model, labour force and gross fixed capital formation are the two key macroeconomic variables, which impact real GDP in the economy [65]. Darvishi and Varedi [66] explain that gross fixed capital formation is an intermediary for the development of capital stock in the economy. GFCF is used as a dependent variable in a number of studies [17-20,67,68]. Labour force is also a key input in the process of production [67].

The research questions have been postulated in the form of the four testable hypotheses. The relationship between renewables and economic growth has been studied in various contexts, as the review of the literature has established. In this study, we essentially wanted to measure the differential impact of renewable energy production across developed and developing countries. A number of scholars have proposed that more research is required in this critical, yet under-researched, area [66-69]. Apergis and Payne [68] explain in this context, "In light of the growth of the emerging market economies and their corresponding energy needs, understanding the relative impact of renewable and non-renewable electricity consumption on the process of economic growth is a worthwhile inquiry." In view of this gap in the literature, in this paper we decided to compare a panel of developed and developing countries.

Specifically, the sample in this study is comprised of the top ten highest renewable energy producing developed and developing countries, as ranked by the World Bank [63]. This ensured that countries producing only small amounts of renewable energy are not included in the sample. In countries producing very small quantities of renewable energy, the impact of renewables on economic growth is likely to be negligible. The sample of chosen countries is presented in Table 2 below.

Table 2. Data on sampled countries.

\begin{tabular}{cccccc}
\hline $\mathbf{2 0 1 6}$ & $\begin{array}{c}\text { Real GDP } \\
\text { (2000 US } \\
\text { Dollars) }\end{array}$ & $\begin{array}{c}\text { Gross Fixed } \\
\text { Capital Formation } \\
\text { (GFCF) }\end{array}$ & $\begin{array}{c}\text { Labour } \\
\text { Force } \\
\text { (LF) }\end{array}$ & $\begin{array}{c}\text { Renewable Energy } \\
\text { Production (Kilowatt } \\
\text { Hour) (REP (kWh)) }\end{array}$ & $\begin{array}{c}\text { Fossil Fuel } \\
\text { (Kilowatt Hour) } \\
\text { (FF (kWh)) }\end{array}$ \\
\hline Austria & $409 \mathrm{Bn}$ & $93 \mathrm{Bn}$ & $4 \mathrm{M}$ & $9 \mathrm{Bn}$ & $10 \mathrm{Bn}$ \\
Brazil & $2423 \mathrm{Bn}$ & $495 \mathrm{Bn}$ & $101 \mathrm{M}$ & $58 \mathrm{Bn}$ & $135 \mathrm{Bn}$ \\
Canada & $1780 \mathrm{Bn}$ & $425 \mathrm{Bn}$ & $20 \mathrm{M}$ & $30 \mathrm{Bn}$ & $130 \mathrm{Bn}$ \\
Chile & $259 \mathrm{Bn}$ & $60 \mathrm{Bn}$ & $9 \mathrm{M}$ & $7 \mathrm{Bn}$ & $38 \mathrm{Bn}$ \\
China & $8333 \mathrm{Bn}$ & $3874 \mathrm{Bn}$ & $787 \mathrm{M}$ & $230 \mathrm{Bn}$ & $3985 \mathrm{Bn}$ \\
Germany & $3646 \mathrm{Bn}$ & $724 \mathrm{Bn}$ & $42 \mathrm{M}$ & $143 \mathrm{Bn}$ & $332 \mathrm{Bn}$ \\
Spain & $1371 \mathrm{Bn}$ & $283 \mathrm{Bn}$ & $23 \mathrm{M}$ & $71 \mathrm{Bn}$ & $100 \mathrm{Bn}$ \\
France & $2748 \mathrm{Bn}$ & $593 \mathrm{Bn}$ & $30 \mathrm{M}$ & $29 \mathrm{Bn}$ & $25 \mathrm{Bn}$ \\
United & $2643 \mathrm{Bn}$ & $432 \mathrm{Bn}$ & $33 \mathrm{M}$ & $59 \mathrm{Bn}$ & $192 \mathrm{Bn}$ \\
Kingdom & $942 \mathrm{Bn}$ & $305 \mathrm{Bn}$ & $123 \mathrm{M}$ & $11 \mathrm{Bn}$ & $190 \mathrm{Bn}$ \\
Indonesia & $2131 \mathrm{Bn}$ & $684 \mathrm{Bn}$ & $495 \mathrm{M}$ & $67 \mathrm{Bn}$ & $984 \mathrm{Bn}$ \\
India & $2043 \mathrm{Bn}$ & $344 \mathrm{Bn}$ & $25 \mathrm{M}$ & $62 \mathrm{Bn}$ & $145 \mathrm{Bn}$ \\
Italy & $5914 \mathrm{Bn}$ & $1382 \mathrm{Bn}$ & $66 \mathrm{M}$ & $63 \mathrm{Bn}$ & $847 \mathrm{Bn}$ \\
Japan & $1179 \mathrm{Bn}$ & $254 \mathrm{Bn}$ & $55 \mathrm{M}$ & $14 \mathrm{Bn}$ & $225 \mathrm{Bn}$ \\
Mexico & $251 \mathrm{Bn}$ & $53 \mathrm{Bn}$ & $43 \mathrm{M}$ & $11 \mathrm{Bn}$ & $54 \mathrm{Bn}$ \\
Philippines & $11 \mathrm{Bn}$ & $18 \mathrm{M}$ & $4 \mathrm{Bn}$ & $2 \mathrm{Bn}$ \\
Romania & $50 \mathrm{Bn}$ & $122 \mathrm{Bn}$ & $5 \mathrm{M}$ & $22 \mathrm{Bn}$ & $2 \mathrm{Bn}$ \\
Sweden & $519 \mathrm{Bn}$ & $92 \mathrm{Bn}$ & $39 \mathrm{M}$ & $10 \mathrm{Bn}$ & $148 \mathrm{Bn}$ \\
Thailand & $382 \mathrm{Bn}$ & $292 \mathrm{Bn}$ & $29 \mathrm{M}$ & $12 \mathrm{Bn}$ & $187 \mathrm{Bn}$ \\
Turkey & $1025 \mathrm{Bn}$ & $3202 \mathrm{Bn}$ & $160 \mathrm{M}$ & $298 \mathrm{Bn}$ & $2751 \mathrm{Bn}$ \\
United States & $16209 \mathrm{Bn}$ & &
\end{tabular}

Source: Authors' compilation on the basis of World Bank [61] and US Energy Information Agency [62]. 


\subsection{Econometric Model and Approach}

In this study we replicated the production modelling framework adopted by Apergis and Payne $[17,19]$. This model is given as follows:

$$
Y_{i t}=f\left(R E_{i t}, F F_{i t}, G F C F_{i t}, L F_{i t}\right)
$$

where

$i=1, \ldots . .20$ for each country in the panel

$t=1995 \ldots . .2016$ refers to the time period of the study

$Y_{i t}=$ Real GDP in billions of constant 2000 US dollars

$R E_{i t}=$ Total renewable electricity consumption defined in billions of kilowatt hours

$F F_{i t}=$ Total fossil fuel electricity consumption defined in billions of kilowatt hours

$G F C F_{i t}=$ Real gross fixed capital formation in billions of constant 2000 US dollars

$L F_{i t}=$ Total labour force in millions

This model is based on the aggregate production function and is used to examine the relationship between renewable and non-renewable energy production and economic growth [17]. It also incorporates measures for labour and capital as a means to circumvent the possibility of omitted variable bias [70]. This model is replicated, in order to establish whether we can accept or reject the four research hypotheses outlined in the literature review. These research hypotheses will be tested using the regression equations below. Each regression equation is tested three times, first using the full panel of 20 countries and then using the developed and developing panels separately.

$$
\begin{aligned}
& \text { A) } \ln G D P_{i t}=\beta_{i} \ln G F C F_{i t}+\beta_{2 i} \ln L F_{i t}+\beta_{3 i} \ln R E P_{i t}+\beta_{4 i} \ln F F_{i t} \\
& \text { B) } \ln G F C F_{i t}=\beta_{i} \ln G D P_{i t}+\beta_{2 i} \ln L F_{i t}+\beta_{3 i} \ln R E P_{i t}+\beta_{4 i} \ln F F_{i t} \\
& \text { C) } \ln L F_{i t}=\beta_{i} \ln G D P_{i t}+\beta_{2 i} \ln G F C F_{i t}+\beta_{3 i} \ln R E P_{i t}+\beta_{4 i} \ln F F_{i t}
\end{aligned}
$$

In these regression equations, GDP, GFCF, LF, REP and FF refer to real gross domestic product, gross fixed capital formation, labour force, renewable energy production and fossil fuel energy production respectively. All variables have been taken in the log-natural (ln) form. The natural logarithms allow the coefficients to be interpreted as elasticities and also help to deal with the dynamic properties of the data [39]. $\beta$ represents the parameters value. $i$ denotes the country variable and $t$ denotes the time dimension.

\subsection{Method of Data Analysis}

In this paper, we employed the panel co-integration model following a number of previous studies $[17,39,43,46]$. The process begins with determining the stationarity of the respective variables, before identifying whether the variables are co-integrated and then finally regressing the variables using the FMOLS test [71,72]. In this study the determination of the stationarity of variables, co-integration and FMOLS regressions are all carried out using the econometrics software Eviews.

The FMOLS is a variant of the standard ordinary least squares OLS regression model. It has some distinct advantages over the standard OLS regression model. It eliminates the endogeneity and serial correlation that is usually created when analysing time series data with OLS [48]. However, this technique suffers from certain limitations as well. Hsiao [72] explains that although this technique has opened up avenues of research that simply could not have been pursued otherwise, it is not a panacea for econometric researchers Panel data, employed in FMOLS regression modelling is heavily dependent on the reliability of the data and the validity of the statistical method used [73]. In our study, the unreliability of the data has been partially mitigated through the use of widely used economic data from respected sources, as well as the use of accepted statistical models. However, some of the 
issues associated with panel data such as heteroscedasticity, autocorrelation and multicollinearity [73] have not been totally eliminated. This has the potential to create spurious findings. For instance, high levels of multicollinearity were found when testing hypothesis 3, demonstrated by high scores of Variance Inflation Factor, which may produce estimates of the "incorrect sign" and of implausible magnitude [73].

When using time series data, it is important that the data used is stationary that is, there is no trend in the data over time. If data is non-stationary, demonstrated by the existence of a unit root, then it is likely the data analysis will produce spurious results. Koop [73] explains that if the dependent and independent variables have unit roots, then the usual regression results might be misleading, often referred to as the spurious regression problem. There is one exception to this rule; when the dependent and independent variables are co-integrated. This refers to the observation that the combination of multiple non-stationary variables may in fact be stationary [73]. If variables are co-integrated, a regression can be undertaken without having to worry about producing spurious results. Co-integration also confirms the existence of a long-run equilibrium relationship between variables [73].

Once co-integration is established, the FMOLS regression model is used to run the regression equations displayed in the previous section. Proposed by Pedroni $[74,75]$, the FMOLS is a variant of the standard ordinary least squares OLS regression model but eliminates the endogeneity and serial correlation that is usually created when analysing time series data with OLS [48]. Pedroni panel co-integration test takes account of heterogeneity by using specific parameters, which are allowed to vary across countries. This circumvents the unrealistic assumption that the vectors of panel co-integration are identical from one country to another [19]. In this study, the determination of the stationarity of variables, co-integration and FMOLS regressions are all carried out using the econometrics software E-views.

\section{Empirical Findings and Discussion}

We used the statistical software E-views and performed the Pedroni (Eagle-Granger based) co-integration test. The null hypothesis is no co-integration. It can be seen from Table 3 that in seven out of the eleven co-integration tests, the null hypothesis can be rejected at the $1 \%$ level. This allows us to be confident that the variables used are co-integrated. To add robustness, a second co-integration test was performed (Table 4). The null hypothesis for the Kao Residual Co-integration Test is also no co-integration, which was rejected at $1 \%$ level. This adds further confirmation that the variables can be regressed without having to worry about the spurious regression problem.

Table 3. Pedroni (Eagle-Granger Based) co-integration test (All countries).

\begin{tabular}{ccccc}
\hline \multicolumn{5}{c}{ Null Hypothesis: No Cointegration } \\
\hline \multicolumn{5}{c}{ Trend Assumption: Deterministic Intercept and Trend } \\
\hline & Statistic & Probability & Weighted Statistic & Probability \\
\hline Panel v-statistic & 4.71 & $0.0000^{* * *}$ & 0.89 & 0.1843 \\
Panel rho-statistic & 2.25 & 0.9879 & 3.23 & 0.9994 \\
Panel pp-statistic & -4.30 & $0.0000^{* * *}$ & -2.44 & $0.0072^{* * *}$ \\
Pandel ADF-statistic & -5.71 & $0.0000^{* * *}$ & -4.43 & $0.0000^{* * *}$ \\
Group rho-statistic & 4.50 & 1.0000 & & \\
Grouped PP-statistic & -5.20 & $0.0000^{* * *}$ & & \\
Group ADF-statistic & -5.80 & $0.0000^{* * *}$ & & \\
\hline
\end{tabular}

Note: ${ }^{* * *}$ indicates significance at $1 \%$ level, ${ }^{* *}$ indicates significance at $5 \%$ level, ${ }^{*}$ indicates significance at $10 \%$ level. 
Table 4. Kao residual co-integration test.

\begin{tabular}{|c|c|c|}
\hline \multicolumn{3}{|c|}{ Null Hypothesis: No Co-Integration } \\
\hline \multicolumn{3}{|c|}{ Trend Assumption: No Deterministic Trend } \\
\hline & t-Statistic & Probability \\
\hline ADF & -2.46 & $0.0068^{* * *}$ \\
\hline
\end{tabular}

Note: *** indicates significance at $1 \%$ level. ${ }^{* *}$ indicates significance at $5 \%$ level. ${ }^{*}$ indicates significance at $10 \%$ level.

Given that the variables are co-integrated, the following regression equation can be used to estimate the long run output elasticities using the FMOLS test.

Hypothesis 1. Renewable energy production is a driver of economic growth.

This hypothesis was tested using the following regression equation.

$$
\ln G D P_{i t}=\beta_{i} \ln G F C F_{i t}+\beta_{2 i} \ln L F_{i t}+\beta_{3 i} \ln R E P_{i t}+\beta_{4 i} \ln F F_{i t}
$$

where $\beta_{i}, \beta_{2 i}, \beta_{3 i}$ and $\beta_{4 i}$ represent the coefficient for each variable and $\mathrm{i}$ and $\mathrm{t}$ represent each country and each year respectively. GDP, GFCF, LF, REP and FF refer to real gross domestic product, gross fixed capital formation, labour force, renewable energy production and fossil fuel energy production respectively. Table 5 displays the results of the full panel, developed countries' panel and developing countries' panel respectively. In all three panels, $R^{2}$ is approximately 0.7 . This measures the total variance in real GDP that can be explained by GFCF, LF, REP and FF [66]. Also the Variance Inflation Factor (VIF) is below 10, which shows that the model has acceptable levels of multicollinearity [73].

Table 5. Panel fully modified least squares model results of renewable energy production and economic growth (REP, FF and GDP).

\begin{tabular}{ccccccccccc}
\hline Variables & \multicolumn{7}{c}{ Gross Domestic Product (GDP) (H1) } \\
\hline & \multicolumn{7}{c}{ All Countries } & \multicolumn{2}{c}{ Developed Countries } & \multicolumn{2}{c}{ Developing Countries } \\
\hline & CE & SE & VIR & CE & SE & VIR & CE & SE & VIR \\
\hline GFCF & $0.44^{* * *}$ & -0.02 & 3.2526 & $0.39^{* * *}$ & -0.04 & 1.9719 & $0.39^{* * *}$ & -0.04 & 5.1217 \\
\hline LF & $0.27^{* * *}$ & -0.08 & 2.4745 & $0.31^{* * *}$ & -0.13 & 4.1356 & $0.23^{*}$ & -0.12 & 2.9431 \\
\hline REP & $0.06^{* * *}$ & -0.01 & 2.2103 & $0.05^{* * *}$ & -0.01 & 2.8059 & $0.07^{* * *}$ & -0.01 & 3.3546 \\
\hline FF & $0.07^{* * *}$ & -0.02 & 2.2064 & 0.01 & -0.02 & 1.0146 & $0.11^{* * *}$ & -0.03 & 4.46873 \\
\hline R-squared & & 0.79 & & & 0.79 & & & 0.75 & \\
\hline Adjusted R-squared & & 0.79 & & & 0.8 & & & 0.74 & \\
\hline
\end{tabular}

Notes: ${ }^{* * *}$ indicated significance at $1 \%$ level, ${ }^{* *}$ indicated significance at $5 \%$ level, ${ }^{*}$ indicates significance at $10 \%$ level. Sample: 1995-2014; Cross sections included: 10 (200 observations). Key: GDP = Gross Domestic Product, GFCF $=$ Gross fixed capital formation, $\mathrm{LF}=$ Labour force, $\mathrm{REP}=$ Renewable Energy Production, FF $=$ Fossil Fuels.

From Table 5 one can arrive at a number of conclusions. Firstly, the full panel shows that, keeping all things equal, an increase in the production of electricity from renewable sources, leads to an increase in real GDP by $0.06 \%$ in the long run. These finding support the growth hypothesis and suggests that there is a unidirectional relationship running from renewable energy to economic growth. The results are also in consonance with some other studies employing the same methodology. For instance, Bhattacharya et al [39] used the FMOLS model for a panel of 38 countries and showed that a $1 \%$ increase in renewable energy consumption lead to a $0.1 \%$ increase in output. These findings are also consistent with Apergis and Payne [17] who used FMOLS model and found that 1 per cent increase in renewable energy consumption led to a $0.074 \%$ increase in GDP. However, the REP coefficient found in this study is much smaller than those found in other studies. 
The FMOLS was conducted again using separate panels for developed and developing countries (Table 5). The results demonstrate that renewable energy production has a positive and statistically significant relationship with real GDP. The findings show that in the developing countries' panel, keeping other things equal, a 1 per cent increase in electricity production from renewable energy sources, led to a 0.07 per cent increase in output, compared to $0.05 \%$ increase in case of developed countries. These findings are consistent with Ito [40] who found evidence of a positive relationship between renewable energy production and economic growth for a panel of 42 developing countries. The findings are also in line with other studies by Bhattacharya et al [39] and Omri et al. [38].

Another interesting conclusion that can be drawn from these results is that electricity production from fossil fuels makes no significant contribution to real GDP in the panel of developed countries. On the other hand, in case of developing countries, a 1 per cent rise in electricity production through fossil fuels raises real GDP by 0.11 per cent. This contradicts findings from other studies like Ito [40]. This study found that in developing countries, renewable energy consumption increases GDP but non-renewable energy consumption decreases GDP. However, the findings offer partial support to Apergis and Payne [44] who found evidence of a bi-directional causality between non-renewable energy consumption and GDP growth in a panel of emerging economies. Overall, hypothesis 1 is supported for both the developed and developing countries since renewable energy production was found to be statistically significant in both sets of countries. The affects were found to be slightly higher in the developing panel than the developed, reflected by coefficients of 0.07 and 0.05 respectively. The results also reveal that the Environmental Kuznets curve relationship does not seem to hold true in the context of renewable energy deployments. We were able to demonstrate that the impact of renewable energy deployments in developing countries exceeds that in developed countries.

\subsection{Renewable Energy and Fixed Capital Formation}

To test hypothesis 2, the following regression equation was tested using the FMOLS technique for separate panels of developed and developing countries.

$$
\ln G F C F_{i t}=\beta_{i} \ln G D P_{i t}+\beta_{2 i} \ln L F_{i t}+\beta_{3 i} \ln R E P_{i t}+\beta_{4 i} \ln F F_{i t}
$$

The findings from the three panels: combined panel of developed and developing countries, the developed countries' panel and the developing countries' panel are presented in Table 6 below. In all the three panels, the VIF figures are below 10, indicating acceptable levels of multi-collinearity.

Table 6. Panel fully modified least squares model results of renewable energy production and economic growth (REP, FF and GFCF).

\begin{tabular}{|c|c|c|c|c|c|c|c|c|c|}
\hline \multirow[t]{3}{*}{ Variables } & \multicolumn{9}{|c|}{ Gross Fixed Capital Formation (GFCF) } \\
\hline & \multicolumn{3}{|c|}{ All Countries } & \multicolumn{3}{|c|}{ Developed Countries } & \multicolumn{3}{|c|}{ Developing Countries } \\
\hline & $\mathrm{CE}$ & SE & VIR & $\mathrm{CE}$ & SE & VIR & CE & SE & VIR \\
\hline GDP & $1.537 * * *$ & -0.091 & 5.6548 & $1.350 * * *$ & -0.147 & 4.4673 & $1.405^{* * *}$ & -0.143 & 8.6231 \\
\hline LF & -0.153 & -0.155 & 2.679 & $0.616^{* *}$ & -0.257 & 4.3737 & -0.133 & -0.227 & 3.1163 \\
\hline REP & $-\underset{* * *}{-0.053}$ & -0.016 & 3.0104 & -0.087 & $(-0.087)$ & 3.1753 & -0.007 & -0.03 & 4.308 \\
\hline $\mathrm{FF}$ & 0.047 & -0.04 & 2.365 & -0.023 & -0.023 & 1.0138 & 0.042 & -0.079 & 5.1079 \\
\hline R-squared & & 0.87 & & & 0.86 & & & 0.85 & \\
\hline Adjusted $\mathrm{R}^{2}$ & & 0.87 & & & 0.86 & & & 0.85 & \\
\hline
\end{tabular}


Firstly, it was found in the case of the full panel of developed and developing countries (Table 6) that all else being equal, a $1 \%$ increase in renewable energy production leads to a $0.05 \%$ fall in GFCF. This contradicts findings from Apergis and Payne [17] who demonstrated that renewable energy consumption has a positive effect on GFCF for a panel of OECD countries. This might be attributed to the fact that renewable energy production causes damage to the traditional energy sector and its related supply chain [76]. Often, investment needed to deploy the high capital needs of renewables is financed through bank lending, which competes with lending to other capital-intensive sectors. It has been found that in the case of full crowding out, investment in renewables could have a negative effect on GDP [61].

Secondly, when the same FMOLS regression was carried out using a panel of developed and developing countries' separately (Table 6), it revealed differential results. In the developed countries' panel it was found that a 1\% increase in renewable energy production leads to a fall in GFCF by $0.087 \%$. In contrast, for the developing countries' panel, it was found that the relationship between renewable energy and GFCF is negative and insignificant (probability of 0.8236 ). There have been very few previous studies on the impact of renewable energy production on GFCF for developing countries. Our results are contradictory to Apergis and Payne [44] who found evidence of a positive relationship between renewable energy consumption and GFCF in a panel of 16 emerging countries for the period 1990-2011. However, these findings are in consonance with Salim et al [20] who found no evidence of a relationship between renewable energy consumption and GFCF for a sample of 29 OECD economies for the period 1980-2011. Another probable reason for the insignificant impact of renewable energy production on GFCF in developing countries may be attributed to the fact that these countries are currently highly dependent on import of capital equipment, machinery and supplies used in renewable energy production. Indigenous sources of capital equipment and infrastructure related to renewable energy production is still in the burgeoning state of development in these countries $[10,20,57]$. These renewable projects have not developed appropriate backward and forward linkages in developing economies.

Therefore, hypothesis 2 is not supported and can be rejected for both developed and developing countries. It was found that renewable energy production was found to have a negative and significant effect on GFCF in the full panel of 20 countries and also in the separate panel of ten developed countries. However, in the developing countries' panel a non-significant relationship was observed between renewable energy production and GFCF.

\subsection{Renewable Energy Generation and Job Creation}

The purpose of testing this hypothesis is to identify whether renewable energy production contributes positively to GDP through its effect on labour, a component of the aggregate production function. LF is used as a proxy for labour force participation, replicating Apergis and Payne [17]. The creation of employment is touted as a key benefit of renewable energy deployment in literature. However, the impact of renewable energy production on labour force participation remains inconclusive. In this paper, the impact of renewable energy production on LF is examined here using the following equation where LF is the dependent variable:

$$
\ln L F_{i t}=\beta_{i} \ln G D P_{i t}+\beta_{2 i} \ln G F C F_{i t}+\beta_{3 i} \ln R E P_{i t}+\beta_{4 i} \ln F F_{i t}
$$

No co-integration was observed in the full panel, thus to avoid producing spurious results, only the developed and developing panels were regressed, the results of which are shown in Table 7 below. Using the VIF rule of thumb of 10 used by researchers and practitioners [70], it can be seen that the FMOLS in the developing countries' panel produced high levels of multi-collinearity. However, O'Brien [70] found that VIF values far in excess of 10, 20 or even 40 do not by themselves, discount the results of regression analyses. The adjusted R-squared value of 0.79 shows that $79 \%$ of the variability 
in labour force can be determined by the four variables GDP, GFCF, REP, FF. The findings and analysis of the developed and developing panel regression are discussed below.

Table 7. Panel fully modified least squares model results of renewable energy production and economic growth (REP, FF and GFCF).

\begin{tabular}{|c|c|c|c|c|c|c|}
\hline \multirow[t]{3}{*}{ Variables } & \multicolumn{6}{|c|}{ Labour Force (LF) } \\
\hline & \multicolumn{3}{|c|}{ Developed Countries } & \multicolumn{3}{|c|}{ Developing Countries } \\
\hline & $\mathrm{CE}$ & SE & VIR & $\mathrm{CE}$ & SE & VIR \\
\hline GDP & $0.21 * *$ & $(0.08)$ & 9.2475 & 0.14 & -0.101 & 16.6345 \\
\hline GFCF & $0.09 * *$ & $(0.04)$ & 4.3169 & -0.01 & $(0.054)$ & 11.0903 \\
\hline REP & $0.23^{* * *}$ & ()0.007 & 3.8777 & -0.02 & -0.015 & 4.1957 \\
\hline $\mathrm{FF}$ & 0.02 & -0.014 & 1.009 & 0.19 & -0.036 & 4.2755 \\
\hline R-squared & & 0.79 & & & 0.79 & \\
\hline Adjusted $\mathrm{R}^{2}$ & & 0.79 & & & 0.79 & \\
\hline
\end{tabular}

Notes: *** indicated significance at $1 \%$ level, ${ }^{* *}$ indicated significance at $5 \%$ level, ${ }^{*}$ indicates significance at $10 \%$ level. Sample: 1995-2016; Cross sections included: 10 (200 observations). Key: LF = Labour force, GFCF $=$ Gross fixed capital formation, GDP = Gross Domestic Product, REP= Renewable Energy Production, FF = Fossil Fuels.

In the developed countries' panel (Table 7), ceteris paribus, REP was found to have a statistically significant and positive effect on labour, represented by a coefficient of 0.227 . These findings are consistent with a number of other influential studies on the inter-linkages between renewable energy production and labour force participation [60,61]. However, our findings contradict other studies such as Apergis and Payne [17-19] Salim et al. [20] and Frondel et al. [62]. These studies found that there was no causal relationship between renewable energy production and economic growth. In contrast, the results of the developing countries' panel (Table 7) shows that there is no significant relationship between renewable energy production and LF. This may be attributed to the fact that renewable energy projects have not gained widespread acceptability across many developing countries. In some countries, issues of exploitation of local populations by renewable energy production has emerged [77-79]. In addition to this the labour intensities of various stages of renewable energy production including production, manufacturing of equipment, transportation and sales have not been clearly estimated so far $[55,56]$.

To conclude, the hypothesis can be accepted in the developed countries' panel and rejected in the developing countries' panel.

\subsection{Differential Impact of Renewable Energy Generation on Developed and Developing Countries}

In order to test this hypothesis we looked at the results of hypothesis 1-3 as a whole. These are listed in Table 8 below, in order to identify whether renewable energy production has a differential impact on the economies of developed and developing countries. Firstly, in the panel of developed countries, renewable energy production has a positive effect on GDP through its contributions to labour. Renewable energy production also has a positive impact on GDP of developed countries. However, this positive effect does not seem to flow from factors such as total labour force and gross fixed capital formation. It can thus be inferred that the positive impact on GDP flows through factors like total factor productivity and trade balances. These channels are however beyond the scope of the present study. 
Table 8. Summary of hypothesis 1-3.

\begin{tabular}{lcccc}
\hline \multicolumn{1}{c}{ Hypothesis } & \multicolumn{2}{c}{ Developed } & \multicolumn{2}{c}{ Developing } \\
\hline \multicolumn{1}{c}{ H1; H2; H3 } & Coefficient & Probability & Coefficient & Probability \\
\hline $\begin{array}{l}\text { Renewable energy generation is one of } \\
\text { the drivers of economic growth. }\end{array}$ & 0.05 & $0.0000^{* * *}$ & 0.07 & $0.0000^{* * *}$ \\
\hline $\begin{array}{l}\text { Renewable energy generation increases } \\
\text { fixed capital formation. }\end{array}$ & -0.08 & $0.0000^{* * *}$ & -0.01 & 0.8236 \\
\hline $\begin{array}{l}\text { Renewable energy generation has a } \\
\text { positive impact on the labour force. }\end{array}$ & 0.21 & $0.0010^{* * *}$ & -0.02 & 0.1695 \\
\hline
\end{tabular}

Secondly, the impact of renewable energy production on GDP was found to be higher in developing countries as compared to developed countries. This may be explained by the fact that much of the growth in renewables has come from developing countries in recent years [37]. Thirdly, the lack of a significant relationship between REP and GFCF in the developing countries' panel diverges from the authors expectations that increased use of renewables would be mirrored by an increase in GFCF since low-wage developing countries are often the largest producers and exporters or renewable technologies However, these findings might be explained by the fact that photovoltaic cells and mini-grids used in many developing countries such as India do not require capital-intensive infrastructure and distribution channels [21]. On the other hand, in developed countries renewable energy is often generated from solar farms and wind farms, which makes significant contributions to capital formation [21].

Lastly, renewable energy production was found to have a positive impact on total labour force in developed countries and no significant impact on developing countries. This may be explained by the fact that the impact of renewables on labour depends upon the number of stages of production that are carried out locally. The design and development part of renewable energy deployment is pre-dominantly taking place in developed economies, only the low-end manufacturing jobs are being carried out in developing countries [77,78].

From this discussion, it can be inferred that Hypothesis 4 is supported and can be accepted based on the differential impact of renewable energy production across developed and developing countries.

\section{Conclusions and Policy Recommendations}

This paper contributes to the existing literature on the relationship between renewable energy production and economic growth. We analysed the relationship between renewable energy production and economic growth, using three key economic variables: real GDP, capital and labour supply for a panel of twenty developed and developing economies (1995-2016). The key results from this research revealed that there exists a statistically significant and positive relationship between renewable energy production and economic growth for both developed and developing economies. These findings confirm the existence of growth hypothesis and imply that renewable energy can be an important source of sustainable economic growth in the future. Our findings are in consonance with a number of other studies $[24,39,42,43]$.

This study also investigated the contribution of renewable energy production to capital formation and labour force participation. These are key components of the aggregate production function. The findings differed between developed and developing countries. In the developed countries' panel, it was found that renewable energy production has a statistically significant impact on labour force. However, it does not have a significant impact on capital formation. On the other hand, in the developing countries' panel renewable energy production did not have a significant impact on neither capital formation nor labour force participation. One reason for this may be that it is only post 2015-2016 that many developing countries have begun to invest heavily in renewable energy 
deployment [55]. However, this is unlikely to have been captured in the present study since post 2016 data is currently not available.

These findings have contributed to the literature on the inter-linkages between renewable energy production and economic growth, especially so by estimating and comparing the differential impact of renewable energy production on developing and developed countries' separately. In addition, there have been few previous studies on the effects of renewable energy production on capital formation and labour force participation. This research provides new and rich insights into the channels through which renewable energy production influences economic growth. Moreover, in this study we use renewable energy production as the main dependent variable, unlike most previous studies, which chose renewable energy consumption as the main dependent variable.

The interdependence between renewable energy production and economic growth has been re-affirmed for both developed and developing countries. However, our results suggest that the stage of economic development of a country must be considered while devising policies to promote renewable energy production. In this research we have not taken account of factors such as total factor productivity and trade balances in the model. These are important channels through which renewable energy deployment can impact economic growth, especially so in the context of developing countries. Some scholars have propounded that in the future western countries may substitute imports of fossil fuels from middle-eastern countries, with renewable energy imports from developing countries like China [62]. Additionally, this research may be complemented with other studies, which look at the country specific factors such as government policy institutional structures and regulatory barriers, impacting renewable energy production [36].

Author Contributions: All authors contributed equally to this paper. N.S. and B.R. conceptualized the paper together, N.S. and B.R. planned the structure of the paper and undertook the review of literature. N.S. wrote the first draft of the paper. The data work for this paper was carried out by B.R. R.N. conducted the final spelling and grammar check.

Funding: This research received no external funding.

Conflicts of Interest: The authors declare no conflicts of interest.

\section{References}

1. Smil, V. Energy in Nature and Society: General Energetics of a Complex System, illustrated ed.; The MIT University Press: Cambridge, MA, USA, 2008; pp. 18-29.

2. Brown, K. Human development and environmental governance: A reality check. In Governing Sustainability, 2nd ed.; Adger, N., Jordan, A., Eds.; Cambridge University Press: Cambridge, UK, 2008; pp. 101-164.

3. IEA. World Energy Outlook. 2016. Available online: https://www.iea.org/weo/ (accessed on 25 January 2016).

4. Nematollahi, O.; Hoghooghi, H.; Rasti, M.; Sedaghat, A. Energy demands and renewable energy sources in the Middle East. Renew. Sustain. Energy Rev. 2016, 54, 1172-1181. [CrossRef]

5. Bettini, G.; Lazaros, K. Exploring the limits of peak oil: Naturalising the political, de-politicising energy. Geogr. J. 2013, 179, 331-341. [CrossRef]

6. Living Planet Report; WWF International: Gland, Switzerland, 2014; Available online: https://www. worldwildlife.org/pages/living-planet-report-2014 (accessed on 12 January 2019).

7. Jacobs, M. Green Growth: Economic Theory and Political Discourse; Working Paper No. 108; Centre for Climate Change Economics and Policy: London, UK, 2012.

8. Hodbod, J.; Tomei, J. Demystifying the Social Impacts of Biofuels at Local Levels: Where is the Evidence? Geogr. Compass 2013, 7, 478-488. [CrossRef]

9. Friedman, T. Hot, Flat and Crowded: Why We Need a Green Revolution and How it Can Renew America; Straux and Giraus: New York, NY, USA, 2008; pp. 24-89.

10. Kasperowicz, R.; Pinczyński, M.; Khabdullin, A. Modeling the power of renewable energy sources in the context of classical electricity system transformation. J. Int. Stud. 2017, 10, 264-272. [CrossRef]

11. Arndt, C.; Pauwk, K.; Thurlow, J. Biomass and Economic Development: A computable General Equilibrium Analysis for Tanzania; Discussion Paper No. 966; International Food Policy Research Institute: Washington DC, USA, 2016. 
12. REN21. Renewables 2017: Global Status Report; REN21 Secretariat: Washington, DC, USA, 2017.

13. Fang, Y. Economic welfare impacts from renewable energy consumption: The China experience. Renew. Sustain. Energy Rev. 2011, 15, 5120-5128. [CrossRef]

14. Sovacool, B.K. The political economy of energy poverty: A review of key challenges. Energy Sustain. Dev. 2013, 16, 272-282. [CrossRef]

15. Cai, W.; Wang, C.; Chen, J.; Wang, S. Green economy and green jobs: Myth or reality? The case of China's power generation sector. Energy 2011, 36, 5594-6003. [CrossRef]

16. Kanase-Patil, A.B.; Saini, R.P.; Sharma, M.P. Integrated renewable energy systems for off grid rural electrification of remote areas. Renew. Energy 2010, 35, 1342-1349. [CrossRef]

17. Apergis, N.; Payne, J.E. Renewable energy consumption and economic growth: Evidence from a panel of OECD countries. Energy Policy 2010, 38, 656-660. [CrossRef]

18. Apergis, N.; Payne, J.E. Renewable energy consumption and growth in Eurasia. Energy Econ. 2010, 32, 1392-1397. [CrossRef]

19. Apergis, N.; Payne, J.E. On the causal dynamics between renewable and non-renewable energy consumption and economic growth in developed and developing countries. Energy Syst. 2011, 2, 299-312. [CrossRef]

20. Salim, R.A.; Hassan, K.; Shafei, S. Renewable and non-renewable energy consumption and economic activities: Further evidence from OECD countries. Energy Econ. 2014, 44, 350-360. [CrossRef]

21. Hall, C.A.S.; Lambert, J.G.; Balogh, S.B. EROI of different fuels and the implications for society. Energy Policy 2014, 64, 141-152. [CrossRef]

22. Weißbach, D.; Rupchert, G.; Huke, A.; Czerski, K.; Gottlieb, S.; Hussein, A. Energy intensities, EROIs and energy payback times of electricity generation power plants. Energy 2013, 52, 210-221. [CrossRef]

23. International Energy Outlook; US Energy Information Agency: Washington, DC, USA, 2010.

24. Ito, $\mathrm{K} . \mathrm{CO}_{2}$ emissions, renewable and non-renewable energy consumption and economic growth: Evidence from a panel for developing countries. Int. Econ. 2017, 151, 1-6. [CrossRef]

25. Dinda, S. Environmental Kuznets Curve Hypothesis: A survey. Ecol. Econ. 2004, 49, 431-455. [CrossRef]

26. Boluk, G.; Mert, M. Fossil and renewable energy consumption, GHGs and economic growth: Evidence from a panel of EU countries. Energy 2014, 60, 1-8.

27. Selden, T.M.; Song, D. Environmental quality and development: Is there a Kuznet's curve for air pollution emissions? J. Environ. Econ. Manag. 1994, 27, 147-162. [CrossRef]

28. Lamla, M.J. Long-run determinants of pollution: A robustness analysis. Ecol. Econ. 2009, 69, 135-144. [CrossRef]

29. Apergis, N.; Ozturk, I. Testing environmental Kuznets curve hypothesis in Asian countries. Ecol. Indic. 2015, 52, 16-22. [CrossRef]

30. Jebli, M.; Youseef, S.; Ozturk, I. Testing environmental Kuznets curve hypothesis: The role of renewable and non-renewable energy consumption and trade in OECD countries. Ecol. Indic. 2009, 60, 824-831. [CrossRef]

31. Jebli, M.; Youssef, S.B. The environmental Kuznets curve, economic growth, renewable and non-renewable energy and trade in Tunisia. Renew. Sustain. Energy Rev. 2015, 47, 173-185. [CrossRef]

32. Ozturk, I.; Acaravci, A. $\mathrm{CO}_{2}$ emissions, energy consumption and economic growth in Turkey. Renew. Sustain. Energy Rev. 2010, 14, 3220-3225. [CrossRef]

33. Ozokcu, S.; Ozdemir, O. Economic growth, energy and environmental Kuznets curve. Renew. Sustain. Energy Rev. 2017, 72, 639-647. [CrossRef]

34. Al-Mulali, U.; Fereidouni, H.G.; Lee, J.Y. Examining the bi-directional long run relationship between renewable energy consumption and GDP growth. Renew. Sustain. Energy Rev. 2013, 22, 209-222. [CrossRef]

35. Bilgili, F.; Ozturk, I. Biomass energy and economic growth nexus in G7 countries: Evidence from dynamic panel data. Renew. Sustain. Energy Rev. 2015, 49, 132-138. [CrossRef]

36. Lopez-Menendez, A.J.; Perez, R.; Moreno, B. Environmental costs and renewable energy: Re-visiting the Environmental Kuznets Curve. J. Environ. Manag. 2014, 145, 368-373. [CrossRef]

37. Armaneu, D.S.; Vintila, G.; Gherghina, S.C. Does Renewable Energy Drive Sustainable Economic Growth? Multivariate Panel Data Evidence for EU-28 countries. Energies 2017, 10, 381-401.

38. Omri, A.; Ben Mabrouk, N.; Sassi-Tmar, A. Modelling the causal linkages between nuclear energy, renewable energy and economic growth in developed and developing countries. Renew. Sustain. Energy Rev. 2015, 14, $3220-3225$. 
39. Bhattacharya, M.; Paramati, S.R.; Ozturk, I.; Bhattacharya, S. The effect of renewable energy consumption on economic growth: Evidence from top 38 countries. Appl. Energy 2016, 162, 733-741. [CrossRef]

40. Ito, K. Renewable and non-renewable energy consumption and economic growth: Evidence from a panel for developing countries. Int. Econ. 2017, 15, 69-74.

41. Inglesi-Lotz, R. The impact of renewable energy consumption to economic growth: A panel data application. Energy Econ. 2016, 53, 58-63. [CrossRef]

42. Pao, H.T.; Fu, H.C. Renewable energy, non-renewable energy and economic growth in Brazil. Renew. Sustain. Energy Rev. 2013, 25, 381-392. [CrossRef]

43. Ozturk, I.; Bilgili, F. Economic growth and biomass consumption nexus: Dynamic panel analysis for Sub-Saharan African countries. Appl. Energy 2015, 137, 110-116. [CrossRef]

44. Apergis, N.; Payne, J.E. The renewable energy consumption-growth nexus in Central America. Appl. Energy 2012, 88, 343-347. [CrossRef]

45. Kahia, M.; Aissa, M.S.B.; Lanouar, C. Renewable and non-renewable energy use-economic growth nexus: The case of MENA net oil importing countries. Renew. Sustain. Energy Rev. 2017, 71, 127-140. [CrossRef]

46. Sadorsky, P. Renewable energy consumption and income in emerging economies. Energy Policy 2009, 37, 4021-4028. [CrossRef]

47. Menyah, K.; Wolde-Rufael, Y. $\mathrm{CO}_{2}$ emissions, nuclear energy, renewable energy and economic growth in the US. Energy Policy 2010, 38, 2911-2915. [CrossRef]

48. Lise, W.; Van Montfort, K. Energy consumption and GDP in Turkey: Is there a co-integration relationship? Energy Econ. 2007, 29, 1166-1178. [CrossRef]

49. Ocal, O.; Aslan, A. Renewable energy consumption-economic growth nexus in Turkey. Renew. Sustain. Energy Rev. 2013, 28, 494-499. [CrossRef]

50. Menegaki, A.N. Growth and renewable energy in Europe: A random effects model with evidence of neutrality hypothesis. Energy Econ. 2011, 88, 488-501. [CrossRef]

51. Yildirim, E.; Sarac, S.; Aslan, A. Energy consumption and economic growth in USA: Evidence from renewable energy. Renew. Sustain. Energy Rev. 2012, 16, 6770-6774. [CrossRef]

52. Vaona, A. Granger non-causality tests between (non)renewable energy consumption and output in Italy since 1861: The (ir)relevant structural breaks. Energy Policy 2012, 45, 226-236. [CrossRef]

53. Huang, B.N.; Hwang, M.J.; Yang, C.W. Causal relationship between energy consumption and GDP growth revisited: A dynamic panel data approach. Ecol. Econ. 2008, 53, 58-63. [CrossRef]

54. Ntanos, S.; Kyriakopoulos, G.; Chalikias, M.; Arabatzis, G.; Skordoulis, M. Public Perceptions and Willingness to Pay for Renewable Energy: A Case Study from Greece. Sustainability 2018, 10, 687. [CrossRef]

55. Alper, A.; Oguz, O. The role of renewable energy consumption in economic growth: Evidence from asymmetric causality. Renew. Sustain. Energy Rev. 2016, 60, 953-959. [CrossRef]

56. Kharlamova, G.; Nate, S.; Chernyak, O. Renewable energy and security for Ukraine: Challenge or smart way. J. Int. Stud. 2016, 9, 88-115. [CrossRef]

57. Rodríguez-Monroy, C.; Mármol-Acitores, G.; Nilsson-Cifuentes, G. Electricity generation in Chile using non-conventional renewable energy sources-A focus on biomass. Renew. Sustain. Energy Rev. 2018, 81, 937-945. [CrossRef]

58. Michaels, R.; Murphy, R.P. Green Jobs-Fact or Fiction? Energy Policy 2009, 32, 45-89.

59. Wei, M.; Patadia, S.; Kammen, D.M. How Many Jobs Can the Clean Energy Industry Generate in the US? Energy Policy 2010, 38, 919-931. [CrossRef]

60. Farroukhi, R.; Lopez-Pena, A.; Kieffer, G.; Nagpal, D.; Hawila, D.; Khalid, A.; Fernandez, A. Renewable Energy Benefits: Measuring the Economics; IRENA International Renewable Energy Agency: Abu-Dhabi, UAE, 2016; pp. 34-117.

61. Duscha, V.; Ragwitz, M.; Breitschopf, B.; Schade, W.; Walz, R.; Pfaff, M. Employment and Growth Effects of Sustainable Energies in the European Union; European Commission: Karlsruhe, Germany, 2014; pp. $27-31$.

62. Frondel, M.; Ritter, N.; Schmidt, C.M.; Vance, C. Economic impacts from the promotion of renewable energy technologies: The German experience. Energy Policy 2010, 38, 4048-4056. [CrossRef]

63. World Bank. World Development Indicators. 2018. Available online: https://datacatalog.worldbank.org/ dataset/world-development-indicators (accessed on 23 February 2018).

64. Energy Information Agency. US Energy Information Energy. 2018. Available online: https://www.eia.gov (accessed on 2 January 2018). 
65. Mankiw, N.G. Macroeconomics; Palgrave McMillan: London, UK, 2016.

66. Darvishi, H.; Varedi, S. Assessment of the Contemporaneous Impacts of Gross Domestic Product and Renewable Energy Consumption, Applying the Dynamic Panel Data: Evidence from Developed Countries. Appl. Energy 2017, 8, 159-166.

67. Bradsher, K. China Leads Global Race to Make Clean Energy. New York Times. 2010. Available online: http://www.nytimes.com/business/energy/environment (accessed on 2 June 2018).

68. Apergis, N.; Payne, J.E. A time varying coefficient approach to the renewable and non-renewable electricity consumption-growth nexus: Evidence from a panel of emerging market economies. Energy Sources Part B Econ. Plan. Policy 2014, 9, 101-107. [CrossRef]

69. Pockock, I. Europe Should Look at Consumption of Renewables Not Just Production. Energypost.eu. 2017. Available online: http://energypost.eu/europe-look-consumption-renewables-just-production/ (accessed on 5 March 2018).

70. O'Brien, R.M. A caution regarding rules of thumb for variance inflation factors. Qual. Quant. 2007, 41, 673-690. [CrossRef]

71. Lutkepohl, H. Non-causality due to omitted variables. J. Econom. 1982, 19, 367-378. [CrossRef]

72. Hsiao, C. Benefits and limitations of panel data. Econom. Rev. 1985, 4, 121-174. [CrossRef]

73. Koop, G. Analysis of Economic Data, 3rd ed.; Wiley Publishers: Hoboken, NJ, USA, 2009; pp. $14-27$.

74. Pedroni, P. Fully Modified OLS for Heterogeneous Co-integrated Panels. In Nonstationary Panels, Panel Cointegration and Dynamic Panels; Badi, H.B., Thomas, B., Fomby, R., Hill, C., Eds.; Emerald Publishers: New York, NY, USA, 2001; pp. 93-130.

75. Pedroni, P. Purchasing power parity tests in cointegrated panels. Rev. Econ. Stat. 2012, 83, 727-731. [CrossRef]

76. Mathiesen, B.V.; Lund, H.; Karlsson, K. 100\% renewable energy systems, climate mitigation and economic growth. Appl. Energy 2011, 88, 488-501. [CrossRef]

77. Năsulea, C. The effects of fiscal policy instability on wind energy resource development in Romania. Econ. Sociol. 2014, 7, 51-59. [CrossRef]

78. Akella, A.K.; Saini, R.P.; Sharma, M.P. Social, economical and environmental impacts of renewable energy systems. Renew. Energy 2011, 34, 390-396. [CrossRef]

79. Singh, N. Sustainability Crisis: A Critical Evaluation of Green Energy Policies. Econ. Polit. Wkly. 2017, 52, 66-69.

(C) 2019 by the authors. Licensee MDPI, Basel, Switzerland. This article is an open access article distributed under the terms and conditions of the Creative Commons Attribution (CC BY) license (http://creativecommons.org/licenses/by/4.0/). 